\title{
BENIGN PROSTATIC HYPERPLASIA: CLINICOPATHOLOGICAL STUDY OF 138 CASES
}

\author{
Abhilash Singh', Vivek Ambedkar², A.P.S. Gaharwar ${ }^{3}$, Vikas Singh $^{4}$, Dheer Singh Rana ${ }^{5}$ \\ ${ }^{1}$ Senior Resident, Department of Surgery, G.T.B. Hospital and U.C.M.S., Delhi. \\ ${ }^{2}$ Senior Resident, Department of Surgery, G.T.B. Hospital and U.C.M.S., Delhi. \\ ${ }_{3}^{3}$ Medical Superintendent, Professor and H.O.D., Department of Surgery, Govt. Shyam Shah Medical College, Rewa, Madhya Pradesh. \\ ${ }^{4}$ Senior Resident, Department of Urology, S.M.S. Medical College, Jaipur, Rajasthan. \\ ${ }^{5}$ Senior Resident, Department of Surgery, G.T.B. Hospital and U.C.M.S., Delhi.
}

\section{ABSTRACT}

\section{AIMS AND OBJECTIVES}

To study the incidence of Benign Prostatic Hyperplasia (BPH) in reference to age of the patients, to study the common symptoms and signs of BPH and classify on the basis of American Urological Association Symptoms Score (AUASS), to evaluate the role of various investigations, to study the relation of weight/volume and size of prostate, and to grade the prostate on the basis of AUASS.

\section{MATERIAL AND METHODS}

Total 138 patients with symptoms of BPH were selected and detailed history was elicited with special reference to AUASS, according to which BPH was graded, investigated properly, and managed accordingly.

\section{RESULTS}

Overall incidence of BPH out of total patients admitted (8562) in surgical wards during period of one year was found $1.61 \%$. Majority of the patients were in the age group 61-70 years and average age in present study was 67.8 years. According to AUASS, most of the patients (62.32\%) had moderate grade symptoms (Score 8-19) followed by patients (37.68\%) had severe symptoms (Score $20-35$ ). On digital rectal examination, $73.18 \%$ of the patients had grade II prostate, $14.42 \%$ had grade III, and grade I in $12.31 \%$. The blood urea and serum creatinine levels were normal in majority of the patients, $62.77 \%$ and $58.69 \%$ respectively. On USG prostate, most of the patients (65.81\%) had prostatic weight in range of 41-60 grams and majority of the patients (47.22\%) had PVR volume of urine ranging between $101-200 \mathrm{~mL}$. Weight of prostatic specimen on prostatectomy showed that most of the patients (64.86\%) had prostatic weight in range of 41-60 grams. On histopathological examination of prostatectomy samples, it was found that $91.90 \%$ of specimens showed BPH and rest $8.10 \%$ were suggestive for carcinoma prostate.

\section{CONCLUSION}

$\mathrm{BPH}$ is a condition intimately related to ageing, which needs treatment when symptoms are bothersome and reduces the quality of life. Patients with mild-to-moderate enlargement of the prostate in $5^{\text {th }}$ and $6^{\text {th }}$ decade of life often respond to watchful waiting and medical treatment. Patients presenting with acute or chronic retention with or without haematuria finally needs surgical intervention.

\section{KEYWORDS}

Benign Prostatic Hyperplasia, Prostate, American Urological Association, AUASS, IPSS, Lower Urinary Tract Symptoms.

HOW TO CITE THIS ARTICLE: Singh A, Ambedkar V, Gaharwar APS, et al. Benign prostatic hyperplasia: clinicopathological study of 138 cases. J.Evolution Med. Dent. Sci. 2016;5(60):4198-4203, DOI: 10.14260/jemds/2016/958

\section{INTRODUCTION}

Senile enlargement of the prostate or BPH is an ancient and universal ailment of the ageing population. This geriatric problem is a very distressing and disabling disease and should be properly managed keeping in view the already waning physical reserve of the patient. The causes of BPH are not fully known, but the overgrowth of smooth muscle tissue and glandular epithelial tissue is attributed to a number of different causes such as ageing, late activation of cell growth, genetic factors, and hormonal causes. ${ }^{1}$ The prostate is a walnut-sized gland made of two lobes or regions enclosed by an outer layer of tissue, which surrounds the urethra, the canal

Financial or Other, Competing Interest: None.

Submission 04-06-2016, Peer Review 01-07-2016,

Acceptance 07-07-2016, Published 28-07-2016.

Corresponding Author:

Dr. Abhilash Singh,

D-333, Second Floor,

Anand Vihar

East Delhi-110092,

Delhi, India.

E-mail: drabhilashsingh03@gmail.com

DOI: $10.14260 /$ jemds $/ 2016 / 958$ through which urine passes out of the body. The enlarged gland has been proposed to contribute the overall LUTS.1,2,3,4 Benign enlargement of prostate occurs in nearly all men as they grow older, but only one in ten is likely to need a surgeon. BPH may or may not be symptomatic when BPH produces symptoms, it is termed clinical BPH. Prostatic enlargement rarely causes symptoms before age of 40 years, but more than half of men in their sixties and as many as $90 \%$ in their seventies and eighties have some symptoms of BPH. Patients of BPH may present with clinical features like frequency, urgency, nocturia, intermittency, decreased stream of urine, and hesitancy. In severe cases, the patient may develop urinary retention, kidney blockage (Hydronephrosis), or renal failure. $5,6,7$

The AUASS is recommended as the symptoms scoring instrument used in the initial assessment of each patient presenting with symptoms of prostatism. When the AUASS System is used, symptoms classified as mild (0 to 7), moderate ( 8 to 19 ), and severe (20 to 35). The symptoms score used as the primary determinant of plan the treatment, treatment response, or disease progression in the followup period. The 
treatment aims at relieving hindrances of the free flow of urine by obviating the enlarged prostate gland at the bladder neck by one of the many surgical procedures available, or else, the patient has to lead a permanent catheter life. Almost, $85 \%$ of men with medically treated BPH are pleased with their choice when surveyed 1 year after treatment commencement. ${ }^{8}$ Parallel developments in surgery, medical instrumentation, and radiation sciences also served as successful treatment for BPH. ${ }^{9}$ Transurethral Resection of Prostate (TURP) is a gold standard treatment for symptomatic BPH and severe LUTS, which is only available in major centres with trained specialist and resectoscopic instruments. Other popular and common operation is suprapubic transvesical prostatectomy.4,10,11 Patient often present with acute retention of urine with varying degree of renal impairment, hence are catheterised and kept on drugs and investigated for surgical intervention on later dates.5,6,7

In our institute, large number of the patients of both sexes and all ages with urinary symptoms are admitted throughout the year. Majority of the elderly male above the age of 55 years presents with symptoms of BPH of various ranges, which prompted us to take up the present study.

\section{MATERIAL AND METHODS}

The present study was carried out in Department of Surgery, Govt. Shyam Shah Medical College and associated S.G. Memorial Hospital, Rewa (M.P.) for the period of one year.

Patients were admitted through Surgical OPD or Casualty with symptoms of BPH. On admission, detailed history and presenting complaints with special reference to AUASS were recorded, quick clinical examination was done, and treated according to acute symptoms.

\section{Exclusion Criteria}

Patients who died or left hospital within 24 hours of admission after relief of their acute symptoms were excluded from the study.

A thorough general and systemic examination was carried out to ascertain the general status and to rule out any significant associated problem. A thorough per abdomen examination was done to rule out any associated disease of liver, spleen, kidney, etc. Suprapubic region was examined for presence of distended bladder. All hernial sites examined carefully. A careful DRE was done for perineum, anal tone, faecal matter, prostate (size, surface, consistency, tenderness, and overlying bowel mucosa), and finger staining on finger withdrawal.

Blood grouping and crossmatch, $\mathrm{CBC}$, coagulation profile, RBS, RFT, urine for routine microscopic examination, urine for culture sensitivity test, and x-ray chest and KUB were done in all patients as basic investigations, USG abdomen/prostate was done to know the size of prostate, prostatic volume/weight, and PVR volume of urine. ECG and Echocardiography was done as indicated. Findings were recorded on predesigned proforma. The patients with retention of urine were catheterised and treated with drugs like alpha-adrenergic blocker, 5-alpha reductase inhibitor, antibiotics, analgesics, and urinary alkalisers for 15 days. Catheter free trial with medicines was given for 15 days. The patients with history of recurrent retention of urine, recurrent catheterisation, and failed catheterisation with or without haematuria or with vesical calculus were subjected to suprapubic cystostomy/suprapubic cystolithotomy under local or spinal anaesthesia. After stabilisation, investigation, and review of the patients, they were subjected to suprapubic transvesical prostatectomy under spinal or general anaesthesia. Weight/volume of the prostatic specimens were measured and subjected for histopathological examination. Patients were managed in postoperative period and discharged with or without urethral catheter and followed up in surgical OPD with histopathological reports.

\section{RESULTS}

Results were analysed in present study, maximum (46.37\%) patients belonged to age group of $61-70$ years, then $24.63 \%$ in the age group of $71-80$ years, and $20.28 \%$ in the group of 51 60 years. Eldest patient was 95 years old and the youngest was of 45 years (Average age in present study was 67.8 years). Most of the patients studied were from the rural area (81.15\%). Majority of the patients (31.15\%) were labourer by occupation, next most common group was farmer (28.98\%).

Distribution of patients according to AUA Symptoms Score (1st) Sense of Incomplete Emptying revealed score of 2 in almost half $(47.82 \%)$ of the patients followed by score 3 in $33.33 \%$ of the patients. (Table I).

\begin{tabular}{|c|c|c|c|}
\hline Sl. No. & Score & No. of Patients & Percentage \\
\hline 1 & 0 & 00 & 00 \\
\hline 2 & 1 & 03 & 2.17 \\
\hline 3 & 2 & 66 & 47.82 \\
\hline 4 & 3 & 46 & 33.33 \\
\hline 5 & 4 & 21 & 15.21 \\
\hline 6 & 5 & 04 & 2.89 \\
\hline \multicolumn{2}{|c|}{ Total } & 138 & 100.0 \\
\hline \multicolumn{4}{|c|}{$\begin{array}{c}\text { Table I: Distribution of Patients According to Sense of } \\
\text { Incomplete Emptying }(n=138)\end{array}$} \\
\hline
\end{tabular}

Distribution of patients according to AUA Symptoms Score (2nd) Frequency of micturition revealed score of 2 in almost half $(47.82 \%)$ of the patients followed by score 3 in 33.33\% and score 4 in $15.21 \%$ of the patients. (Table II).

\begin{tabular}{|c|c|c|c|}
\hline Sl. No. & Score & No. Patients & Percentage \\
\hline 1 & 0 & 00 & 00 \\
\hline 2 & 1 & 02 & 1.44 \\
\hline 3 & 2 & 66 & 47.82 \\
\hline 4 & 3 & 46 & 33.33 \\
\hline 5 & 4 & 21 & 15.21 \\
\hline 6 & 5 & 03 & 2.17 \\
\hline \multicolumn{2}{|c|}{ Total } & 138 & 100.0 \\
\hline \multicolumn{4}{|c|}{$\begin{array}{l}\text { Table II: Distribution of Patients According to } \\
\text { Frequency of Micturition }(n=138)\end{array}$} \\
\hline
\end{tabular}

Distribution of patients according to AUA Symptoms Score ( $3^{\text {rd }}$ ) Intermittency revealed score of 2 in majority (37.68\%) of the patients followed by score 1 in $32.60 \%$ and score 4 in $19.56 \%$ of the patients. (Table III).

\begin{tabular}{|c|c|c|c|}
\hline Sl. No. & Score & No. of Patients & Percentage \\
\hline 1 & 0 & 04 & 2.89 \\
\hline 2 & 1 & 45 & 32.60 \\
\hline 3 & 2 & 52 & 37.68 \\
\hline 4 & 3 & 27 & 19.56 \\
\hline 5 & 4 & 10 & 7.24 \\
\hline 6 & 5 & 00 & 00 \\
\hline \multicolumn{2}{|c|}{ Total } & 138 & 100.0 \\
\hline \multicolumn{4}{|c|}{$\begin{array}{l}\text { Table III: Distribution of Patients According to } \\
\text { Intermittency }(n=138)\end{array}$} \\
\hline
\end{tabular}


Distribution of patients according to AUA Symptoms Score ( $4^{\text {th }}$ ) Urgency revealed score of 2 in majority (42.02\%) of the patients followed by score 1 in $31.15 \%$ and score 3 in $11.59 \%$ of the patients. (Table IV).

\begin{tabular}{|c|c|c|c|}
\hline Sl. No. & Score & No. of Patients & Percentage \\
\hline 1 & 0 & 10 & 7.24 \\
\hline 2 & 1 & 43 & 31.15 \\
\hline 3 & 2 & 58 & 42.02 \\
\hline 4 & 3 & 16 & 11.59 \\
\hline 5 & 4 & 10 & 7.24 \\
\hline 6 & 5 & 01 & 0.72 \\
\hline \multicolumn{2}{|c|}{ Total } & 138 & 100.0 \\
\hline \multicolumn{4}{|c|}{$\begin{array}{c}\text { Table IV: Distribution of Patients According to } \\
\text { Urgency }(n=138)\end{array}$} \\
\hline
\end{tabular}

Distribution of patients according to AUA Symptoms Score $\left(5^{\text {th }}\right)$ Weak Stream revealed score of 3 in majority (32.60\%) of the patients followed by score 4 in $28.98 \%$, score 5 in $21.01 \%$ and score 2 in $14.42 \%$ of the patients. (Table V).

\begin{tabular}{|c|c|c|c|}
\hline Sl. No. & Score & No. of Patients & Percentage \\
\hline 1 & 0 & 00 & 00 \\
\hline 2 & 1 & 02 & 1.44 \\
\hline 3 & 2 & 20 & 14.42 \\
\hline 4 & 3 & 47 & 32.60 \\
\hline 5 & 4 & 40 & 28.98 \\
\hline 6 & 5 & 29 & 21.01 \\
\hline \multicolumn{2}{|c|}{ Total } & 138 & 100.0 \\
\hline \multicolumn{4}{|c|}{$\begin{array}{l}\text { Table V: Distribution of Patients According to Weak } \\
\text { Stream }(n=138)\end{array}$} \\
\hline
\end{tabular}

Distribution of patients according to AUA Symptoms Score (6th) Straining revealed score of 3 in majority (32.60\%) of the patients followed by score 4 in $31.15 \%$, score 2 and 5 in $18.11 \%$ of the patients for each. (Table VI).

\begin{tabular}{|c|c|c|c|}
\hline Sl. No. & Score & No. of Patients & Percentage \\
\hline 1 & 0 & 00 & 00 \\
\hline 2 & 1 & 00 & 00 \\
\hline 3 & 2 & 25 & 18.11 \\
\hline 4 & 3 & 45 & 32.60 \\
\hline 5 & 4 & 43 & 31.15 \\
\hline 6 & 5 & 25 & 18.11 \\
\hline \multicolumn{2}{|c|}{ Total } & 138 & 100.0 \\
\hline \multicolumn{4}{|c|}{$\begin{array}{c}\text { Table VI: Distribution of Patients According to } \\
\text { Straining }(n=138)\end{array}$} \\
\hline
\end{tabular}

Distribution of patients according to AUA Symptoms Score

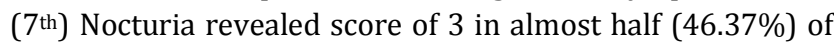
the patients followed by score 3 in $29.71 \%$, score 4 in $16.66 \%$, and score $1 \mathrm{in} 7.32 \%$ of the patients. (Table VII).

\begin{tabular}{|c|c|c|c|}
\hline Sl. No. & Score & No. of Patients & Percentage \\
\hline 1 & 0 & 00 & 00 \\
\hline 2 & 1 & 09 & 7.32 \\
\hline 3 & 2 & 64 & 46.37 \\
\hline 4 & 3 & 41 & 29.71 \\
\hline 5 & 4 & 23 & 16.66 \\
\hline 6 & 5 & 01 & 0.72 \\
\hline \multicolumn{2}{|c|}{ Total } & 138 & 100.0 \\
\hline \multicolumn{4}{|c|}{$\begin{array}{c}\text { Table VII: Distribution of Patients } \\
\text { According to Nocturia }(n=138)\end{array}$} \\
\hline
\end{tabular}

Individual AUA Symptoms Scores were added to grade the symptoms to assess the severity of the disease and it was observed that most (62.32\%) of the patient had moderate grade symptoms. (Table VIII).

\begin{tabular}{|c|c|c|c|}
\hline $\begin{array}{l}\text { Sl. } \\
\text { No. }\end{array}$ & $\begin{array}{c}\text { Grade } \\
\text { ( Score) }\end{array}$ & $\begin{array}{c}\text { No. of } \\
\text { Patients }\end{array}$ & Percentage \\
\hline 1 & Mild (0-7) & 00 & 00 \\
\hline 2 & $\begin{array}{c}\text { Moderate (8- } \\
19)\end{array}$ & 86 & 62.32 \\
\hline 3 & Severe (20-35) & 52 & 37.68 \\
\hline \multicolumn{2}{|c|}{ Total } & 138 & 100.0 \\
\hline
\end{tabular}

Almost half $(47.10 \%)$ of the patients had burning micturition along with urinary complaints included in AUASS. Other significant urinary complaints were retention of urine, pyuria, and haematuria. (Table IX).

\begin{tabular}{|c|c|c|c|}
\hline $\begin{array}{c}\text { Sl. } \\
\text { No. }\end{array}$ & Complaints & $\begin{array}{c}\text { No. of } \\
\text { Patients }\end{array}$ & Percentage \\
\hline 1 & Burning Micturition & 65 & 47.10 \\
\hline 2 & Retention of Urine & 50 & 36.23 \\
\hline 3 & Pyuria & 36 & 26.08 \\
\hline 4 & Haematuria & 20 & 14.42 \\
\hline \multicolumn{3}{|c|}{ Table IX: Distribution of Patients According to Other } \\
Urinary Complaints(n=138) \\
\hline
\end{tabular}

Many of the patients had fever, hernia, constipation, hypertension, DM, and bleeding per rectum as associated complaint along with urinary complaints. (Table X).

\begin{tabular}{|c|c|c|c|}
\hline $\begin{array}{c}\text { Sl. } \\
\text { No. }\end{array}$ & Complaints & $\begin{array}{c}\text { No. of } \\
\text { Patients }\end{array}$ & Percentage \\
\hline 1 & Fever & 29 & 21.01 \\
\hline 2 & Hernia & 27 & 19.56 \\
\hline 3 & Constipation & 22 & 15.94 \\
\hline 4 & H.T.N. & 15 & 10.86 \\
\hline 5 & D.M. & 14 & 10.14 \\
\hline 6 & Bleeding P/R & 12 & 8.69 \\
\hline \multicolumn{3}{|c|}{ Table X: Distribution of Patients According to } \\
Associated complaints(n=138) \\
\hline
\end{tabular}

As per DRE findings, it was observed that most (73.18\%) of the patients had grade II sized prostate. (Table XI).

\begin{tabular}{|c|c|c|c|}
\hline Sl. No. & Grade & No. of Patients & Percentage \\
\hline 1 & I & 17 & 12.31 \\
\hline 2 & II & 101 & 73.18 \\
\hline 3 & III & 20 & 14.42 \\
\hline \multicolumn{2}{|c|}{ Total } & 138 & 100.0 \\
\hline \multicolumn{4}{|c|}{$\begin{array}{c}\text { Table XI: Distribution of Patients According to Prostatic } \\
\text { Size on D.R.E. }(n=138)\end{array}$} \\
\hline
\end{tabular}

As per findings of routine and microscopic examination of urine, it was observed that pus cells were found in $23.91 \%$ of the patients, RBCs in $13.04 \%$, and albumin in $1.44 \%$ of the specimens.

Routine KFT revealed that normal blood urea levels in majority $(62.77 \%)$ of the patients whereas maximum value recorded was $371 \mathrm{mg} \%$ and serum creatinine level was found within normal limits in majority (58.69\%) of the patients whereas maximum value recorded was $10.2 \mathrm{mg} \%$. 
X-ray KUB region findings revealed that vesicle calculus in 8 patients (5.79\%) and Rt. renal calculus in 2 patients $(1.44 \%)$.

USG for prostatic weight revealed that most $(65.81 \%)$ of the patients had prostatic weight in the range of 41-60 grams. (Table XII).

\begin{tabular}{|c|c|c|c|}
\hline Sl. No. & $\begin{array}{c}\text { Range } \\
\text { (grams } / \mathrm{mL} \text { ) }\end{array}$ & $\begin{array}{c}\text { No. of } \\
\text { Patients }\end{array}$ & Percentage \\
\hline 1 & $20-40$ & 18 & 15.38 \\
\hline 2 & $41-60$ & 77 & 65.81 \\
\hline 3 & $61-80$ & 15 & 12.82 \\
\hline 4 & $81-100$ & 06 & 5.12 \\
\hline 5 & $>100$ & 01 & 0.85 \\
\hline \multicolumn{2}{|c|}{ Total } & 117 & 100.0 \\
\hline
\end{tabular}

USG for PVR volume of urine revealed that almost half (47.22\%) of the patients had PVR volume in the range of 101$200 \mathrm{~mL}$ and $12.96 \%$ patients had PVR volume more than 400 mL. (Table XIII).

\begin{tabular}{|c|c|c|c|}
\hline $\begin{array}{c}\text { Sl. } \\
\text { No. }\end{array}$ & $\begin{array}{c}\text { PVR vol. } \\
\text { Range }(\mathbf{m L})\end{array}$ & No. of Patients & Percentage \\
\hline 1 & $0-100$ & 08 & 7.40 \\
\hline 2 & $101-200$ & 51 & 47.22 \\
\hline 3 & $201-300$ & 18 & 16.66 \\
\hline 4 & $301-400$ & 17 & 15.74 \\
\hline 5 & $>400$ & 14 & 12.96 \\
\hline \multicolumn{2}{|c|}{ Total } & $\mathbf{1 0 8}$ & $\mathbf{1 0 0 . 0}$ \\
\hline
\end{tabular}

\section{Table XIII: Distribution of Patients According to PVR vol.} of Urine on USG ( $m L).(n=108)$

Catheter free trial was given to 128 patients with 15 days of medical treatment. The trial was successful in $53.12 \%$ patients and $46.87 \%(n=60)$ of the patients were recatheterised and medical treatment continued for another 15 days.

Second catheter free trial was successful in $21.66 \%(n=13)$ patients and failed in $78.33 \%(n=47)$. Out of 47 patients, 37 (78.72\%) underwent suprapubic prostatectomy.

Weight of prostatectomy specimens were recorded and observed that most of the patients (64.86\%) had prostatic weight in range of 41-60 grams and only one patient had prostate weight more than 100 grams. (Table XIV).

\begin{tabular}{|c|c|c|c|}
\hline Sl. No. & Weight & No. of Patients & Percentage \\
\hline 1 & $20-40$ & 06 & 16.21 \\
\hline 2 & $41-60$ & 24 & 64.86 \\
\hline 3 & $61-80$ & 06 & 16.21 \\
\hline 4 & $81-100$ & 00 & 00 \\
\hline 5 & $>100$ & 01 & 2.70 \\
\hline \multicolumn{4}{|c|}{$\begin{array}{r}\text { Table XIV: Distribution of Patients According to Weight } \\
\text { of Prostate (grams) on Prostatectomy(n=37) }\end{array}$} \\
\hline
\end{tabular}

On correlation of weight of prostate on USG and AUA Symptoms Score $(n=117)$, it was observed that the majority of patients having USG prostatic weight $>60$ grams had severe grades of symptoms (66.66\% on 61-80 grams range) whereas majority of the patients having prostatic weight $<60$ grams had moderate grade symptoms. (Table XV).

\begin{tabular}{|c|c|c|c|c|c|c|}
\hline \multirow[b]{2}{*}{$\begin{array}{l}\text { Sl. } \\
\text { No. }\end{array}$} & \multirow[b]{2}{*}{$\begin{array}{l}\text { Range of } \\
\text { Weight of } \\
\text { Prostatic } \\
\text { Specimen }\end{array}$} & \multicolumn{5}{|c|}{ AUA Symptoms Score } \\
\hline & & Total & $\begin{array}{l}\text { Mode- } \\
\text { rate }\end{array}$ & $\%$ & Severe & $\%$ \\
\hline 1 & $20-40$ & 18 & 13 & 72.2 & 05 & 27.77 \\
\hline 2 & $41-60$ & 77 & 52 & 67.53 & 25 & 32.46 \\
\hline 3 & $61-80$ & 15 & 05 & 33.3 & 10 & 66.66 \\
\hline 4 & 81-100 & 07 & 03 & 42.85 & 03 & 42.85 \\
\hline 5 & $>100$ & 01 & 00 & 00 & 01 & 100 \\
\hline$T a$ & XV: Corre & ion 0 & of $P$ & tate ( & S.) on & Gand \\
\hline
\end{tabular}

Histopathological examination of prostatectomy specimens revealed that BPH in $91.90 \%(n=34)$ of the samples and carcinoma in rest $8.10 \%(n=3)$ that means the incidence of malignancy in prediagnosed patients of BPH was $8.10 \%$, patients were of above the age of 65 years, and were having grade II-III prostate on DRE. Most of the specimens were hard in consistency and size of prostate has no correlation with malignancy. (Table XVI).

\begin{tabular}{|c|c|c|c|c|c|c|c|}
\hline $\begin{array}{c}\text { Sl. } \\
\text { No. }\end{array}$ & $\begin{array}{c}\text { Case } \\
\text { No. }\end{array}$ & $\begin{array}{c}\text { Age } \\
\text { (years) }\end{array}$ & $\begin{array}{c}\text { AUA } \\
\text { Symptoms } \\
\text { Score }\end{array}$ & $\begin{array}{c}\text { Findings of DRE } \\
\text { (Prostate size) }\end{array}$ & $\begin{array}{c}\text { Prostatic wt. on } \\
\text { USG (grams) }\end{array}$ & $\begin{array}{c}\text { Weight of } \\
\text { Prostatic } \\
\text { Specimen } \\
\text { (grams) }\end{array}$ & $\begin{array}{c}\text { Consistency of } \\
\text { Prostatic } \\
\text { Specimen }\end{array}$ \\
\hline 1 & 66 & 80 & 22 & Grade III & 80 & 70 & Hard \\
\hline 2 & 97 & 65 & 18 & Grade II & 50 & 47 & Firm \\
\hline 3 & 112 & 70 & 20 & Grade III & 56 & 50 & Hard \\
\hline \multicolumn{7}{|c|}{ Table XVI: Analysis of Patients of BPH Who Turned Out to be Malignant on } \\
Histological Examination of Their Prostate (n=3/8.10\%)
\end{tabular}

\section{DISCUSSION}

$\mathrm{BPH}$ is a well-known condition characterised by prostatic growth accompanied by LUTS. ${ }^{2}$ Prostatic enlargement happens to almost all men as they get older, but only $10 \%$ are likely to need a surgeon. Urinary discomfort amounting from simple frequency to acute retention and uraemia in old people are recognised since long due to of prostate gland.5,12

\section{Incidence of BPH}

$\mathrm{BPH}$ is the most common benign tumour in men and its incidence is age related. ${ }^{13}$ A recent AUA guidelines (2003) suggests an increase in the incidence of BPH worldwide and predicts by the age of 60 years more than $50 \%$ of men will have microscopic evidence of the disease and by the age of 85 years 
as many as $90 \%$ of men will be affected.4,14 and nearly all men develop microscopic BPH by the age of 90 years. ${ }^{15}$

\section{Age Incidence}

The average age of patients in present study was 67.8 years. The youngest patient was of 45 years old and oldest was of 95 years. Although, BPH is uncommon before age 40 , roughly $50 \%$ of men develop BPH related symptoms at 50 years of age. The incidence of BPH increases by $10 \%$ per decade and reaches $80 \%$ at approximately 80 years of age. 16,17 The estimated prevalence is $25 \%$ in men aged 40 to 79 years. ${ }^{18}$ The slightly higher age incidence in western countries may be attributed to the longer life span of their population. ${ }^{4}$

\section{Presenting Complaints}

BPH clinically manifest as LUTS consisting of irritative symptoms (hesitancy, a weak and interrupted urinary stream, straining to initiate urination, a sensation of incomplete bladder emptying). ${ }^{1}$ It has been classically stated that from 25 to $50 \%$ of individuals with microscopic and macroscopic evidence of BPH will progress to clinical BPH.19 In the present series, major complaints of BPH were increased frequency of micturition, urgency, nocturia, urge incontinence, enuresis, burning micturition, pyuria, haematuria, hesitancy, poor stream, dribbling, sense of incomplete emptying, intermittency, chronic and acute retention of urine. Among these, nocturia, straining, increased frequency, and micturition was present in $100 \%$ of cases. Prolonged obstruction may eventually lead to acute urinary retention (AUR), recurrent urinary tract infection, haematuria, bladder calculi, and renal insufficiency. 20

\section{AUA Grading}

The prevalence of urinary symptom associated with BPH was studied in community-based nationwide sample of 2011 Frenchmen 50-80 years old, symptoms was assessed by AUA index. After exclusion of prostatic cancer, $6.5 \%$ of subject reported having undergone prostate surgery. Nocturia and repeated voiding within 2 hours were the most prevalent symptoms in $67 \%$ and $13 \%$ and respective ranked between 1 and 7,8 and 19 , and 20 or more. 4,6

\begin{tabular}{|c|c|c|c|c|c|c|}
\hline \multirow{2}{*}{ Sl. No. } & \multirow{2}{*}{ Author } & \multirow{2}{*}{ Year } & \multirow{2}{*}{ Place } & \multicolumn{3}{|c|}{ AUASS Grade } \\
\cline { 5 - 7 } & & & Mild & Mod. & Severe \\
\hline 1 & Robert F & 2010 & USA & $22.2 \%$ & $46.1 \%$ & $32.7 \%$ \\
\hline 2 & Anil Kapoor & 2012 & Canada & $16.9 \%$ & $47.1 \%$ & $32.0 \%$ \\
\hline 3 & Rohit Singh & 2007 & India & $3.0 \%$ & $61.8 \%$ & $35.0 \%$ \\
\hline 4 & Present Series & 2014 & India & $0.0 \%$ & $62.3 \%$ & $37.6 \%$ \\
\hline \multicolumn{6}{|c|}{ Table XVII: Correlation Between AUASS } \\
Grades in Different Series \\
\hline
\end{tabular}

It is evident from above table that in western countries more number of the patients presents early for health assistance than our region and it proves that the patients in this region do not seek medical advice unless in dire emergency. In present study, about $61.85 \%$ patients were presented with retention of urine.

DRE done in all patients to estimate the approximate size of prostate gland and screening for carcinoma prostate. Prostatic size does not correlate with symptom severing, degree of obstruction, or treatment outcome significantly.5,7 In present study, all the patient were found to have enlarged prostate and most of the patients i.e., $73.18 \%$ scored grade II followed by Grade III in $14.42 \%$ and grade I in $12.31 \%$ that means patients present in our setup on later stage of disease.

\section{Investigations}

In present study, average preoperative haemoglobin was 11.4 gm\% ranging from 7.2-16 gm\%. This clearly denotes the moderate anaemia and need for blood transfusion in higher percent of cases undergone for operative procedures. Blood urea and serum creatinine levels estimation gives an idea of the renal functions in case with enlarged prostate and which was found to be raised in some patients due to BPH or other associated diseases. In present series, the values are slightly higher than those reported by other workers possibly because majority of the cases came with retention of urine of long duration. Patients of BPH or LUTS are more prone to develop vesical calculus possibly because of chronic retention/stasis of urine. ${ }^{14}$

USG Abdomen and Prostate: 1. Prostatic Weight: In present series, it was noted that most of the patients $(65.81 \%)$ had prostatic weight in range of 41-60 grams and belongs to moderate AUASS group. Next most common group (15.38\%) was of patients having 20-40 grams prostate. It shows that most of the patients present in later stage of disease. It is also important to mention here that the most of the patients who presented with complaints of BPH had moderate grade on AUASS System in present series and as the size of prostate increases with age, severity of symptoms shifted towards moderate-to-severe grades. 2. Post-Void Residual volume: In present study, on USG examination, most of the patients (47.22\%) had PVR volume of urine ranging between 101-200 $\mathrm{mL}$, next most common group (16.66\%) belongs to range of 201-300 mL. Studies indicate that residual urine normally ranges from 0.09 to $2.24 \mathrm{~mL}$ with mean being $0.53 \mathrm{~mL}, 78 \%$ of normal men have PVR volume less than $5 \mathrm{~mL}$, and $100 \%$ have volumes of less than $12 \mathrm{~mL}$. Residual urine volume does not correlate well with other signs of symptoms of prostatism. ${ }^{6}$

Prostatic carcinoma is more common in India compared to other Asian Countries. ${ }^{21}$ Incidence of prostatic cancer increases rapidly with age than any other cancer. Thus, the numbers of prostate cancer cases are expected to increase as average age of men is increasing. 22

\section{SUMMARY AND CONCLUSION}

$\mathrm{BPH}$ is a condition intimately related to ageing. Although, it is not life threatening, its clinical manifestation, LUTS reduces the patient's quality of life. BPH needs treatment when symptoms are bothersome and reduces the quality of life. Treatment offered to patients was watchful waiting with medical treatment (Drugs) or surgical treatment. Patient with mild-to-moderate enlargement of the prostate in $5^{\text {th }}$ and $6^{\text {th }}$ decade of life often respond to watchful waiting and medical treatment. Drugs like alpha-receptor antagonist and 5-alpha reductase inhibitor has inconstant results with definite symptomatic improvement, which may not correspond to investigatory results. Patients presenting with acute or chronic retention with or without haematuria finally needs surgical intervention. TURP remains gold standard treatment, yet many centres offers open prostatectomy as one-stage or two-stage procedures. 


\section{ACKNOWLEDGMENT}

We are very much thankful to the Prof. Dr. G. P. Shrivastava, Ex H.O.D., Department of Surgery, Govt. Shyam Shah Medical College and associated S.G. Memorial Hospital, Rewa, Madhya Pradesh, India, for providing us the opportunity to study the cases and also encouraging us to report the study.

\section{REFERENCES}

1. Miller J, Tarter TH. Combination therapy with dutasteride and tamsulosin for the treatment of symptomatic enlarged prostate. Clin Interv Ageing 2009; 4:251-8.

2. Chapple CR, Smith D. The pathophysiological changes in the bladder obstructed by BPH. Br J Urol 1994; 73(2):117-23.

3. Cheih-Lung C. Current medical treatment for BPH/lower urinary tract symptoms. Incont pelvic floor dysfunct 2007;1(Suppl 2):15-9.

4. Donnell RF. Guidelines and management of benign prostatic enlargement. American Urological Association Education and Research, Inc 2010.

5. Blandy JP. Benign prostatic enlargement. British Medical Journal 1971;1(5739):31-5.

6. Nickel JC, Thomas FW, Paterson RF, et al. 2010 Update: guidelines for the management of BPH. Canadian Urological Association 2010;4(5):310-6.

7. Kapoor A. BPH, management in primary care setting. Canadian Journal of Urology 2012;19(Suppl 1):10-7.

8. Kaplan SA. AUA guidelines and their impact on the management of BPH an update. Rev Urol 2004;6(Suppl 9):S46-52.

9. Garg G, Singh D, Saraf S. Management of BPH an overview of alpha-adrenergic antagonist. Biol Pharm Bull 2006;29(8):1554-8.

10. Jepsen JW, Bruskewitz RC. Recent developments in the surgical management of benign prostatic hyperplasia. Urology 1998;51(4 A Suppl):23-31.
11. Condie JD, Cutherell L, Mian A. Suprapubic prostatectomy for benign prostatic hyperplasia in rural Asia: 200 consecutive cases. Urology 1999;54(6):1012-6.

12. Alberto B, Capitanio U, Suardi N, et al. BPH and its aetiologies. European Urology 2009;8(13):865-71.

13. Presti JC. Neoplasms of the prostate gland. In: Smith's general Urology. Tanagho EA, Annich JW, (Eds). International edition. McGraw-Hill 2000:399-421.

14. Paolone DR. Benign prostatic hyperplasia. Causes Diagnosis and Treatment-Clinical Key 2010;26(2): 223-39.

15. Berry SJ, Coffey DS, Walsh PC, et al. The development of BPH with age. J Urol 1984;132(3):474-9.

16. De la Rosette J, Alivizatos G, Madersbacher S, et al. EAU guidelines on BPH. Eur Urol 2001;40:256-63.

17. Irani J, Brown CT, Emberton $M$, et al. A review of guidelines on BPH and lower urinary tract symptoms, are all guidelines the same? BJU Int 2003;92(9):937-42.

18. Mozes B, Cohen YC, Olmer L, et al. Factors affecting change in quality of life after prostatectomy for benign prostatic hypertrophy: the impact of surgical techniques. J Urol 1996;155(1):191-6.

19. Verhamme KM, Dieleman JP, Bleumink GS, et al. Incidence and prevalence of lower urinary tract symptoms suggestive of BPH in primary care-the Triumph project. Eur Urol 2002;42(4):323-8.

http://simplelink.library.utoronto.ca.myaccess.library.u toronto.ca/url.cfm/23633.

20. Curtis NJ. BPH Cost and treatment outcomes. Am J Manag Care 2006;4:251-8.

21. Krishna V. Textbook of pathology. Orient Longman 2004:889-905

22. Carter HB, Coffey DS. The prostate: an increasing medical problem. Prostate 1990;16(1):39-48. 